\title{
Experimental evaluation and genetic programming based modeling of the compressive strength of concretes produced with various strength classes of cements
}

\author{
Kasım MERMERDAŞ ${ }^{1}$ * (D), Süleyman IPEK ${ }^{2}$ (D), Burak BOZGEYIK ${ }^{3}$ (iD) \\ ${ }^{1}$ Harran University, Civil Engineering Department, Sanliurfa, Turkey \\ ${ }^{2}$ Bingöl University, Civil Engineering Department, Bingöl, Turkey \\ ${ }^{3}$ Hasan Kalyoncu University, Civil Engineering Department, Gaziantep, Turkey
}

\begin{abstract}
This study aimed to propose a prediction model for estimation of strength of concretes with various cements and mixture proportions. The strength of the samples produced with three different types of cement at different rates of water-to-cement ratios and cement richness were investigated experimentally and evaluated statistically. Three type of cement possessing 28day strengths of $32.5,42.5$, and $52.5 \mathrm{MPa}$ was used in the production of concretes. The concretes were produced at cement richness values of 300,400 , and $500 \mathrm{~kg} / \mathrm{m} 3$ and w/c rates at changing levels within the interval of between 0.3 and 0.6. By this way, combined influences of cement strength, amount of cement and w/c ratio was experimentally investigated. Totally 36 mixes were cast then the compressive strength values were examined after specified moist curing periods ( 7 and 28 day). A statistical study were conducted on the experimental results and the significances of the cement strength, w/c values and amount of cement on the compressive strength of the concretes were assessed. Another crucial focus of the current paper is to generate an explicit expression to predict the compressive strength of the concretes tackled with the current study. To derive an explicit formula for estimation, a soft computing method called gene expression programming (GEP) was benefited. The GEP model was also compared with a less complicated estimation model developed by multi linear regression method. The results revealed that compressive strength of the samples were significantly influenced by cement type and aggregate-to-cement ratio. It was observed that there is a high correlation between experimental and predicted values obtained from the proposed GEP model.
\end{abstract}

\section{Article info \\ History:}

Received:09.07.2019

Accepted:15.04.2020

Keywords:

Compressive strength,

Gene Expression

Programming,

Multiple Linear

Regression,

Statistical evaluation

\section{Introduction}

The strength of the cement directly influences the concrete and mortar characteristics especially the compressive strength characteristic [1,2]. During the recent years, different cement strength classes are utilized in diverse construction works. In addition to cement strength class, w/c and cement content are other important factors which affect the performance of concrete. There are many studies evaluating the effects of water and cement content on the strength development of concrete. However, the combined effect of water-to-cement ratio, cement content and strength class of cement on compressive strength of concrete is still insufficient. Mermerdaş et al. [3] modeled compressive strength of metakaolin and calcined kaolins modified concrete by means of Gene Expression Programming (GEP). They indicated that GEP is a beneficial tool for prediction of the strength of concrete. Sayed [4] investigated the predictability of strength of concrete containing different matrix mixtures by using statistical modeling methods. Eight different parameters of time, water, cement, metakaolin, silica fume, superplasticizer, and fine and coarse aggregates were utilized in the experimental program. According to findings in this research, statistical modeling is capable for prediction the compressive strength of concrete. Deshpande et al. [5] used three different data processing methods called artificial neural networks (ANN), model tree (MT), and non-linear regression (NLR) for prediction of the 28-day strength of recycled aggregate concrete. They reported that with minimum number of inputs, ANN 
has a better prediction capability in strength of concretes including reclaimed aggregates than obtained from MT and NLR techniques. However, MT and NLR techniques have advantageous aspects such as MT technique could provide a set of models of discrete complication and precision, and NLR technique could give a single equation which can be easily utilized. Chandwani et al. [6] conducted a study to model strengths of three different types of special concretes which are self-consolidating concrete, high performance concrete, and recycled aggregate concrete. They used ANN for modeling purpose. They used non-destructive test data in the evaluation of the model. According to this study, the ANN is an effective technique that can be used as a predicting tool based on historical data, to estimate the compressive strength of different types of concretes based on mix proportions. More examples can be found in the technical literature regarding the utilization of soft computing based modelling techniques to evaluate mechanical properties of construction materials and structural elements [6].

In the available literature, there has been no study regarding the compressive strength modelling of concretes taking into account the cement classes. A handy tool providing quick interpretation of the compressive strength performance of concretes with different mix compositions and cement types can be obtained through a comprehensive mathematical model. Soft computing techniques are appropriate means for this purpose. GEP can be considered as one of the simplest way among the others. It can yield a simple explicit mathematical expression of physical phenomena. Once this model is transferred via a user friendly software or an interface, the preliminary workload of the researchers can be mitigated.

In this study, the influence of w/c values, amount of cement, and strength class of cement on mechanical property of concrete was experimentally investigated. For this reason, three main concrete mixture groups were determined with respect to cement type of CEM II 32.5, CEM I 42.5 and CEM I 52.5. The cement types were selected regarding to 28-day strength. In each mixture, four different water-to-cement ratios of 0.3 , $0.4,0.5$, and 0.6 and three different cement contents of 300,400 , and $500 \mathrm{~kg} / \mathrm{m}^{3}$ were considered as experimental parameters. Totally 36 different concrete mixtures were designed and their strengths were tested at the age of 7 and 28 days. After the experimental investigation of the mixtures, the results were used in the modeling of the compressive strength of concrete regarding to input parameters of the cement compressive strength, water-to-cement ratio, aggregate-to-cement ratio, and age by using GEP and multiple linear regression analysis (MLR). The results indicated that compressive strength of the concrete is directly influenced by water-to-cement ratio, age, and especially the cement compressive strength. Two different models were obtained from GEP and MLR and their results were compared graphically and statistically.

\section{Experimental Study}

\subsection{Materials}

CEM II 32.5, CEM I 42.5, and CEM I 52.5 types cements having specific gravities of $3.05,3.14$, and 3.15 , which are confirming Turkish Standard requirements, were used in the production of concrete mixtures. Chemical compositions and some critical physical characteristics of the cements are given in Table 1.

Table 1 Chemical compositions and some physical properties of CEM I-52.5, CEM I-42.5, and CEM II-32.5

\begin{tabular}{|c|c|c|c|}
\hline Item & CEM I 52.5 & $\begin{array}{l}\text { CEM I } \\
42.5 \mathrm{R}\end{array}$ & CEM II 32.5 \\
\hline $\mathrm{SiO}_{2}(\%)$ & 18.22 & 18.99 & 20.31 \\
\hline $\mathrm{Al}_{2} \mathrm{O}_{3}(\%)$ & 63.85 & 3.95 & 4.96 \\
\hline $\mathrm{Fe}_{2} \mathrm{O}_{3}(\%)$ & 3.45 & 4.65 & 2.9 \\
\hline $\mathrm{CaO}(\%)$ & 3.65 & 62.76 & 60.48 \\
\hline $\operatorname{MgO}(\%)$ & 1.55 & 2.32 & 1.65 \\
\hline $\mathrm{SO}_{3}(\%)$ & 2.72 & 2.75 & 2.51 \\
\hline $\mathrm{Na}_{2} \mathrm{O}(\%)$ & - & - & 0.26 \\
\hline $\mathrm{K}_{2} \mathrm{O}(\%)$ & 0.2 & - & 0.6 \\
\hline $\mathrm{Cl}^{-}(\%)$ & 0.005 & 0.0063 & 0.01 \\
\hline Insoluble residue & 0.26 & 0.34 & 3.2 \\
\hline Loss on ignition & 1.43 & 0.87 & 6.3 \\
\hline Free lime $(\%)$ & 0.78 & 1.68 & - \\
\hline Specific gravity & 3.15 & 3.14 & 3.05 \\
\hline Le chatelier (mm) & 1 & 1 & 1 \\
\hline $\begin{array}{c}\text { Blaine surface } \\
\text { area }\left(\mathrm{cm}^{2} / \mathrm{g}\right)\end{array}$ & 4,680 & 3,520 & 3,750 \\
\hline
\end{tabular}

The medium and coarse aggregate was river material with a maximum size of $16 \mathrm{~mm}$ for the former and 22.5 $\mathrm{mm}$ for the latter. The fine aggregate which is natural sand of maximum particle size of less than $4 \mathrm{~mm}$. The specific gravity values were 2.65 for natural sand, 2.71 for medium, and 2.77 for coarse aggregates. The particle size distributions of the aggregates were monitored through the sieve analysis and illustrated in Figure 1. 


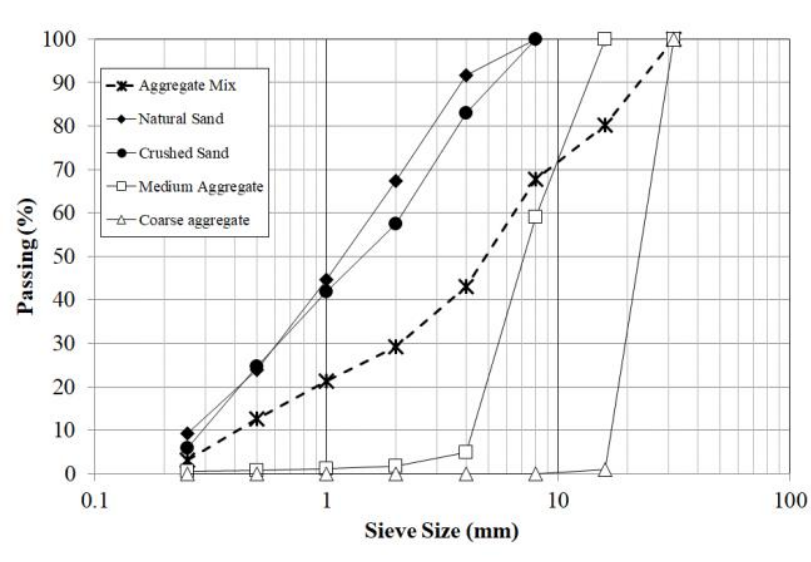

Figure 1. Particle size distribution of the aggregates

\subsection{Mixture design}

The concrete mixtures were grouped in three according to the cement type utilized in the production of concrete. In each group, the concrete mixtures were manufactured considering various cement contents and water-to-cement ratios. 28-day strengths of cements are 32.5, 42.5, and 52.5 MPa confirming Turkish Standard. The w/c ratios were taken as $0.3,0.4,0.5$, and 0.6 and cement content as 300,400 , and $500 \mathrm{~kg} / \mathrm{m}^{3}$. As results, in each group, twelve mixes were designed and totally, thirty six different concrete groups were cast in the current study. The mix proportions of the concrete mixtures are presented in Table 2.

Table 2. Mix proportions for $1 \mathrm{~m}^{3}$ concrete (in $\mathrm{kg} / \mathrm{m}^{3}$ )

\begin{tabular}{ccc}
$\begin{array}{c}\text { Cement } \\
\text { content } \\
\left(\mathbf{k g} / \mathbf{m}^{\mathbf{3}}\right)\end{array}$ & $\begin{array}{c}\text { Water-to-cement } \\
\text { ratio } \\
(\mathrm{w} / \mathrm{c})\end{array}$ & $\begin{array}{c}\text { Proportions of Aggregates } \\
\text { (Coarse/Medium/Natural) }\end{array}$ \\
\hline 300 & 0.3 & \\
400 & 0.4 & $0.2 / 0.3 / 0.5$ \\
500 & 0.5 & \\
\hline
\end{tabular}

\subsection{Concrete casting}

In order to provide a consistent and desirable homogeneity as well as uniformity for all mixtures, the same procedure was followed. For preparing the mixes, a laboratory pan mixer was used. At the end of the production process, fresh mixtures were poured into the moulds. After filling the mould, the specimens were covered with plastic sheet to ensure moisture proofing and preventing plastic shrinkage. They left in the temperature controlled laboratory environment for $24 \mathrm{~h}$ and $20 \pm 1^{\circ} \mathrm{C}$ environment. The specimens were taken out of the molds and transferred to lime saturated curing tanks. The curing periods of 7-day and 28-day was applied. Afterwards, they were tested based on the testing procedure proposed ASTM C39 [27] to specify the 7-day and 28-day strengths of the concretes.

\section{Results and Discussion}

\subsection{Experimental results}

The compressive strength results of the concretes at the end of 7 and 28 days regarding to cement content and water-to-cement ratio with three different cement types are given in Table 3 and the data provided presented this table were graphically shown in Figure 2 .

While the compressive strength values ranged between 19.8 and $80.8 \mathrm{MPa}$ for $7^{\text {th }}$ day compressive strength, the values were determined to be between 25.5 and $94.6 \mathrm{MPa}$ at $28^{\text {th }}$ day. The results indicated that strength of specimens is directly influenced by the cement type and the mix proportions as expected. The highest strength value was obtained for the concrete mixtures produced with CEM I 52.5 cement type regardless the other parameters. Utilization of higher strength cement in concrete improved the quality of the cement paste which in turn is the reason of achieving higher compressive strength.

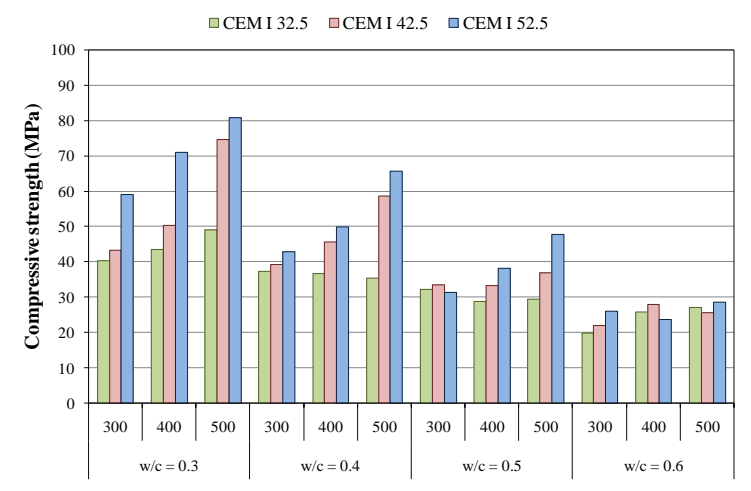

(a)

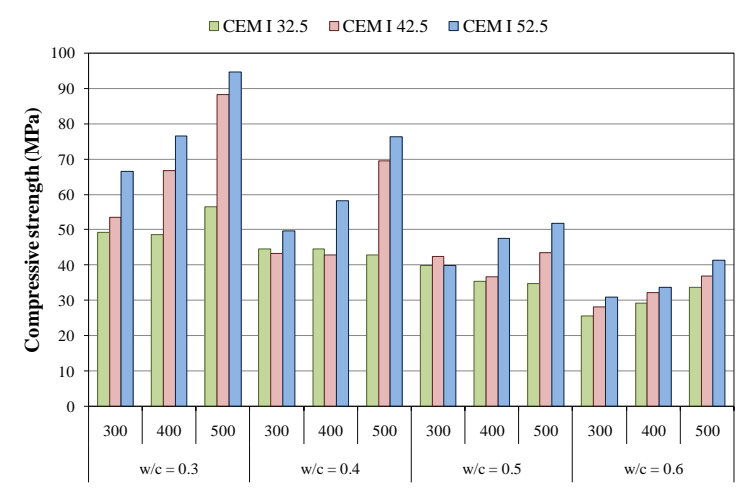

(b)

Figure 2. Compressive strength of the concretes a) 7-day and b) 28-day 
Table 3. Compressive strength of the concretes

\begin{tabular}{|c|c|c|c|c|c|c|c|c|c|c|}
\hline \multirow{2}{*}{$\begin{array}{l}\text { Cement } \\
\text { content } \\
\left(\mathbf{k g} / \mathrm{m}^{3}\right)\end{array}$} & \multirow{2}{*}{$w / c$} & \multirow{2}{*}{$\begin{array}{c}\text { Cement } \\
\text { type }\end{array}$} & \multicolumn{2}{|c|}{$f \mathrm{c}(\mathrm{MPa})$} & \multirow{2}{*}{$\begin{array}{c}\text { Cement } \\
\text { type }\end{array}$} & \multicolumn{2}{|c|}{$f \mathrm{c}(\mathrm{MPa})$} & \multirow{2}{*}{$\begin{array}{c}\text { Cement } \\
\text { type }\end{array}$} & \multicolumn{2}{|c|}{$f \mathrm{c}(\mathrm{MPa})$} \\
\hline & & & 7-day & 28-day & & 7-day & 28-day & & 7-day & 28-day \\
\hline \multirow{4}{*}{300} & 0.3 & & 59.1 & 66.6 & \multirow{12}{*}{$\begin{array}{c}\text { CEM I } \\
42.5\end{array}$} & 43.3 & 53.5 & \multirow{12}{*}{$\begin{array}{c}\text { CEM II } \\
32.5\end{array}$} & 40.2 & 49.3 \\
\hline & 0.4 & & 42.8 & 49.7 & & 39.2 & 43.2 & & 37.3 & 44.6 \\
\hline & 0.5 & & 31.4 & 40.0 & & 33.5 & 42.5 & & 32.1 & 39.9 \\
\hline & 0.6 & & 26.0 & 30.9 & & 22.0 & 28.0 & & 19.8 & 25.5 \\
\hline \multirow{4}{*}{400} & 0.3 & & 70.9 & 76.5 & & 50.2 & 66.8 & & 43.5 & 48.6 \\
\hline & 0.4 & CEM I & 49.8 & 58.2 & & 45.5 & 42.8 & & 36.7 & 44.6 \\
\hline & 0.5 & 52.5 & 38.0 & 47.5 & & 33.2 & 36.7 & & 28.8 & 35.5 \\
\hline & 0.6 & & 23.7 & 33.6 & & 27.8 & 32.3 & & 25.8 & 29.3 \\
\hline \multirow{4}{*}{500} & 0.3 & & 80.8 & 94.6 & & 74.6 & 88.3 & & 48.9 & 56.4 \\
\hline & 0.4 & & 65.7 & 76.3 & & 58.6 & 69.6 & & 35.4 & 42.9 \\
\hline & 0.5 & & 47.8 & 51.7 & & 36.8 & 43.6 & & 29.3 & 34.8 \\
\hline & 0.6 & & 28.5 & 41.4 & & 25.5 & 36.8 & & 27.0 & 33.6 \\
\hline
\end{tabular}

The amount of water relative to cement content had significant influences on the strength, as w/c ratio is raised from 0.3 to 0.6 a systematic reduction in the strength values at both testing ages were observed. The minimum strength values were noted for the mixtures with water-to-cement ratio of 0.6 , almost all of the values were less than $40 \mathrm{MPa}$. The results also illustrated that there is insignificant change in strength of the concrete mixtures produced including CEM II 32.5 type of cement when the cement content is increased from 300 to $500 \mathrm{~kg} / \mathrm{m}^{3}$. At both testing ages, the cement content increasing in the mixtures manufactured with CEM II 32.5 type of cement increased just the strength of the mixture with $\mathrm{w} / \mathrm{c}$ ratio of 0.6 while in the others no remarkable effect was observed. Contrarily, the effectiveness of cement content on the strength was clearly observed in the mixes with CEM I 52.5 type of cement. Increasing the amount of cement resulted the enhancement of strength especially at low w/c values.

Reducing the water-to-cement ratio from highest ratio to lowest one improved the strength performance. For example, in the concrete series produced with CEM I 52.5 type of cement, the $7^{\text {th }}$ day compressive strength values of concretes produced at 300, 400, and 500 $\mathrm{kg} / \mathrm{m}^{3}$ of cement content augmented about $127.3 \%$, $199.0 \%$, and $183.2 \%$, respectively, when w/c is decreased from 0.6 to 0.3 . The increment rates in the $28^{\text {th }}$ day compressive strength are $115.4 \%, 127.6 \%$, and $128.7 \%$ for the same concretes. When the w/c values of the concretes were decreased from 0.6 to 0.3 , in the concrete series obtained by utilization of cement strengths of 42.5 and $32.5 \mathrm{MPa}$, the increment rates of the $7^{\text {th }}$ day strengths of the mixtures cast with 300,400 , and $500 \mathrm{~kg} / \mathrm{m}^{3}$ richness of cement content were, respectively, $96.8 \%, 80.6 \%$, and $192.6 \%$ and $103.0 \%$, $68.4 \%$, and $81.1 \%$ whereas they were, respectively, $90.8 \%, 106.8 \%$, and $140.0 \%$ and $93.3 \%, 66.1 \%$, and $67.9 \%$ for the $28^{\text {th }}$ day strength.
Also, the strengths obtained at $7^{\text {th }}$ and $28^{\text {th }}$ day versus aggregate-to-cement ratio are illustrated in Figures 3a and $3 \mathrm{~b}$, respectively. It can apparently be understood from the figures that the strength of the concretes is improved by augmenting of aggregate-to-cement ratio.

\section{Statistical evaluation and Multiple Linear Regression (MLR)}

Analysis of variance (ANOVA) was used in the evaluation of if the dependent variables are influenced by independent variable. General linear model analysis of variance (GLM-ANOVA), a significant statistical tool, is based on reducing the control variance that helping to assess the effectiveness of parameters. The identification of the statistically significant experimental factor on the strength was determined by analysis at 0.05 level of significance. GLM-ANOVA was applied through a commercial software called "Minitab" to examine the data given in Table 4. The dependent variable was compressive strength while independent variables were the w/c ratio, cement content, and cement compressive strength namely cement type. The general linear model analysis was benefited to determine the effectiveness of the test parameters. Table 4 illustrates the statistical analysis results. The significance of the test parameter on the compressive strength is determined by the p-values. The parameter is acceptable as significant factor on the depended variable if $\mathrm{p}$-value of less than 0.05. Statistical analysis showed that the parameters taken into account have remarkable influences on strength of concrete in both curing ages since the p-values of all parameters are less than 0.05 . The contributions of the factors on the measured test results are also presented in Table 4. Analyzing the contribution levels of the independent variables indicated that the most important parameter in strength of the concretes is w/c ratio at both testing ages. The statistical analysis revealed that the contribution of cement compressive 
strength, namely cement type, and cement content can be underestimated when compared to contribution of water-to-cement ratio.

Table 4. Statistical evaluation of the compressive strength of the concretes

\begin{tabular}{|c|c|c|c|c|c|c|}
\hline Dependent Variable & $\begin{array}{l}\text { Independent } \\
\text { variable }\end{array}$ & $\begin{array}{l}\text { Sequential Sum of } \\
\text { Squares }\end{array}$ & $\begin{array}{l}\text { Computed } \\
\text { F }\end{array}$ & $\begin{array}{l}\mathrm{P} \\
\text { Value }\end{array}$ & $\begin{array}{l}\text { Significanc } \\
\mathrm{e}\end{array}$ & $\begin{array}{l}\text { Contribution } \\
(\%)\end{array}$ \\
\hline \multirow{5}{*}{ 7-day compressive strength } & $f_{\mathrm{cc}}$ & 1064.38 & 11.90 & 0.000 & Yes & 13.05 \\
\hline & $\mathrm{w} / \mathrm{c}$ & 5088.69 & 37.93 & 0.000 & Yes & 62.41 \\
\hline & c & 748.08 & 8.36 & 0.001 & Yes & 9.18 \\
\hline & Error & 1252.31 & - & - & - & 15.36 \\
\hline & Total & 8153.43 & - & - & - & - \\
\hline \multirow{5}{*}{$\begin{array}{l}\text { 28-day compressive } \\
\text { strength }\end{array}$} & $f_{\mathrm{cc}}$ & 1383.8 & 12.95 & 0.000 & Yes & 13.96 \\
\hline & $\mathrm{w} / \mathrm{c}$ & 5927.3 & 36.97 & 0.000 & Yes & 59.80 \\
\hline & $\mathrm{c}$ & 1104.4 & 10.33 & 0.000 & Yes & 11.14 \\
\hline & Error & 1496.3 & - & - & - & 15.10 \\
\hline & Total & 9911.8 & - & - & - & - \\
\hline
\end{tabular}

fc: compressive strength of cement; w/c: water-to-cement ratio; c: cement content

Moreover by using Minitab, a linear equation of observed data was obtained by using multiple linear regression that modeling the relationship between a response variable and two or more descriptor variables.

$$
F_{c}=77.03+0.7074 \times f_{c}-118.81 \times w-3.202 \times a+0.3657 \times
$$

where $\mathrm{F}_{\mathrm{c}}$ is the compressive strength of the concrete, $f_{\mathrm{c}}$, $\mathrm{w}, \mathrm{a}$, and $\mathrm{t}$ are the compressive strength of the cement, water-to-cement ratio, aggregate-to-cement ratio, and testing age, respectively.

In addition, the results at 7 and 28 days are plotted with respect to compressive strength and aggregate-tocement ratio on Figure $3 \mathrm{a}$ and $3 \mathrm{~b}$, respectively. Then, compressive strength results at each testing age were grouped into three according to cement content utilized in the production. Power function fitting was applied on each group. R-square values and power function equations for each group are also illustrated in Figure $3 \mathrm{a}$ and $3 \mathrm{~b}$. According to the results, the higher Rsquare values of 0.825 and 0.843 was achieved in the concretes produced with $300 \mathrm{~kg} / \mathrm{m}^{3}$ cement content at both ages.

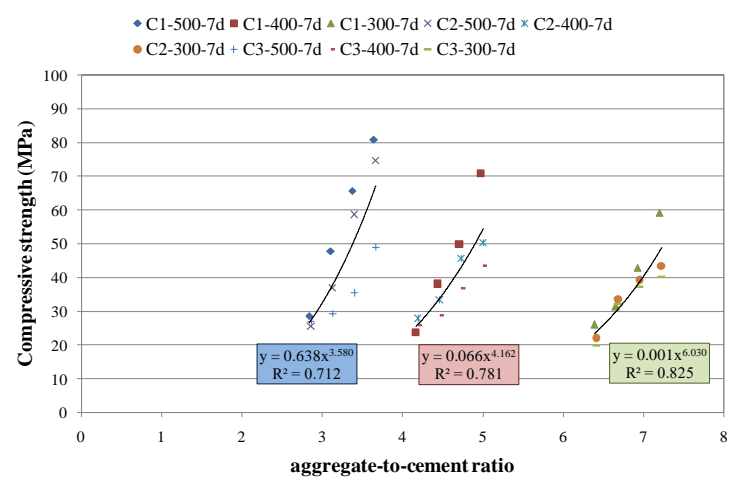

(a)

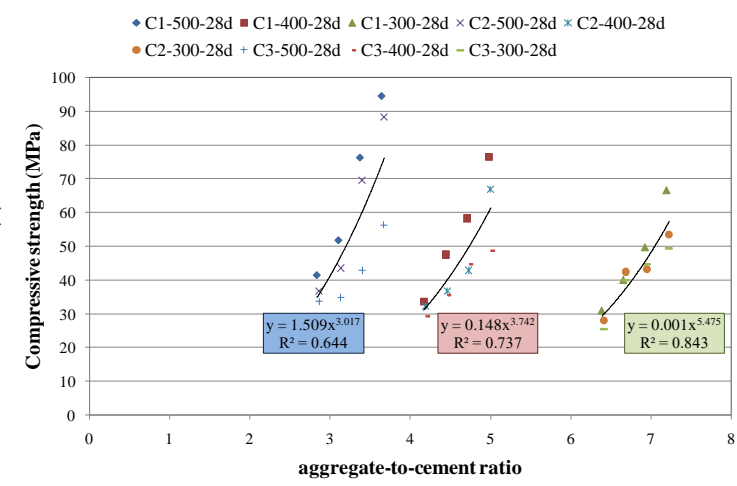

(b)

Figure 3. Compressive strength values versus aggregate-tocement ratio with power function fitting at: a) 7-day and b) 28-day

\section{Development of Estimation Model}

Gene expression programming (GEP), invented by Candida Ferreira [28], uses softwares by statments of the acquired models or presented knowledge [29]. Genetic programming, introduced by Koza [30], is a application of GAs [31]. Solving defined problem by employing a computer program is a commonly used solution. The definition of the problem is the first step in the logic of GP and GAs, and then the program runs to work out the problem in a problem-independent mode [31]. GEP is derived as an enhanced form of aforementioned genetic operators. These three algorithms use almost same genetic operators in the solutions with unimportant differences. Ferreira [28] states that the differences between the three algortihms denoted as "in GAs the individuals are linear strings of fixed length (chromosomes); in GP the individuals are nonlinear entities of different sizes and shapes (parse trees); and in GEP the individuals are encoded as linear strings of fixed length (the genome or chromosomes) 
which are afterwards expressed as nonlinear entities of different sizes and shapes (i.e., expression trees (ETs) or simple diagram representations)".

The compressive strength of the cements, water-tocement ratios, aggregate-to-cement ratios, and testing ages of concretes with experimental results were regulated to achieve a data set. Table 3 presents the data set which was randomly divided into two groups. "Train set" is one of the sub-data set whereas "Test set" is the other. The mathematical model was derived by using a software named GeneXproTools 4.0. The following expression is the prediction model that was achieved from GEP. The sub-expression trees of the prediction model is also depicted in Figure 4.

$$
\begin{aligned}
& F_{c}=F_{1}+F_{2}+F_{3}+F_{4}+F_{5}+F_{6} \\
& F_{1}=\arccos \left(\sin d_{2}\right)-\tan \left(\sqrt{d_{1}}\right)-d_{0} \times \ln d_{1}-2 \times d_{2} \\
& F_{2}=\sqrt[3]{d_{2}-\left(e^{c 7}\right)^{\ln d_{1}}} \times \tan \left(\tan d_{0}^{2}\right)
\end{aligned}
$$

where $c_{7}=-1.6339$

$$
F_{3}=c_{1}+\frac{\sqrt{d_{1}} \times \log d_{3} \times\left(\arccos d_{1}+c_{5}\right)}{d_{1}}
$$

where $\mathrm{c}_{1}=0.3216, \mathrm{c}_{5}=5.3928$

$F_{4}=\frac{\sqrt[3]{c_{7} \times d_{2}}}{d_{1}} \times \sin \left(\left(c_{3}-d_{2}\right) \times \sqrt{c_{9}}\right)$

where $c_{3}=-6.5469, c_{7}=1.6151, c_{9}=5.384$

$F_{5}=c_{2}-d_{1}-\arctan \left(\tan d_{0} \times \ln d_{1} \times\left(c_{6}+d_{2}\right)\right)$

where $c_{2}=6.2143, c_{6}=-4.1084$

$F_{6}=\sin \left(\left(\tan d_{0}^{2}+\cos e^{d_{3}}\right) \times d_{0} \times\left(c_{6}-d_{2}\right)\right)$

where $c_{6}=-9.6818$

where $F_{c}$ is the compressive strength of concrete, $d_{0}, d_{1}$, $\mathrm{d}_{2}$, and $\mathrm{d}_{3}$ are the compressive strength of the cement, water-to-cement ratio, aggregate-to-cement ratio, and testing age, respectively.

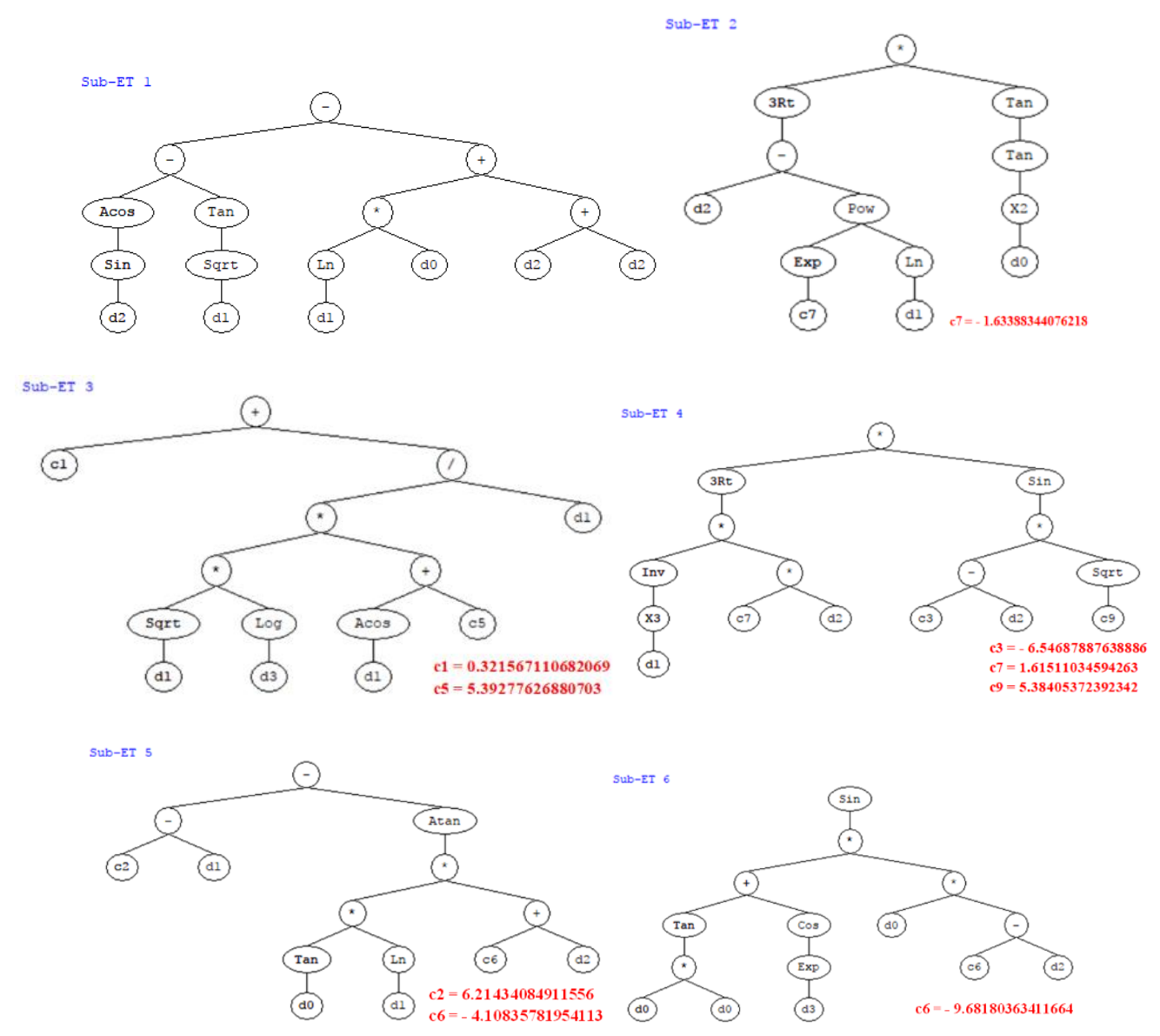

Figure 4. Expression trees for GEP model 


\section{Correlation between estimated experimental compressive strength}

One of the most popular studies among the researchers is correlation of the experimental data. By this way, it is aimed to assess the results reported. To assess the compressive strength of the mixtures, correlating the estimated compressive strength with the laboratory data was performed. The correlation between laboratory data and the estimation values obtained by Multiple Linear Regression (MLR) and predicted by mathematical model generated by GEP are presented in Figure 5a and 5b, respectively. The coefficient of determination, $\mathrm{R}^{2}$, for experimental and predicted compressive strength are also shown on these figures. The higher $R^{2}$ values reflects the higher relation between the parameters. Based on $\mathrm{R}^{2}$ values, it may be determined that there is a strong relation between the estimated and experimental compressive strength for the models achieved by MLR and GEP. But the correlation coefficient of GEP model was higher than that of MLR model. The $\mathrm{R}^{2}$ value of the proposed GEP model was about 0.955 while it was 0.836 for model obtained by MLR.

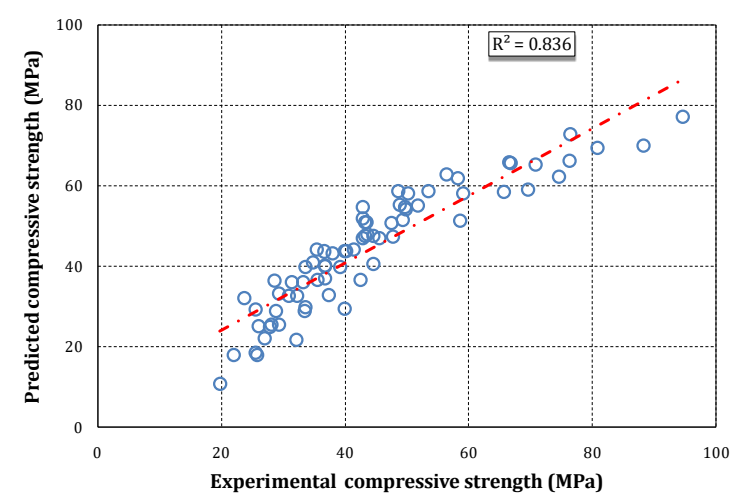

(a)

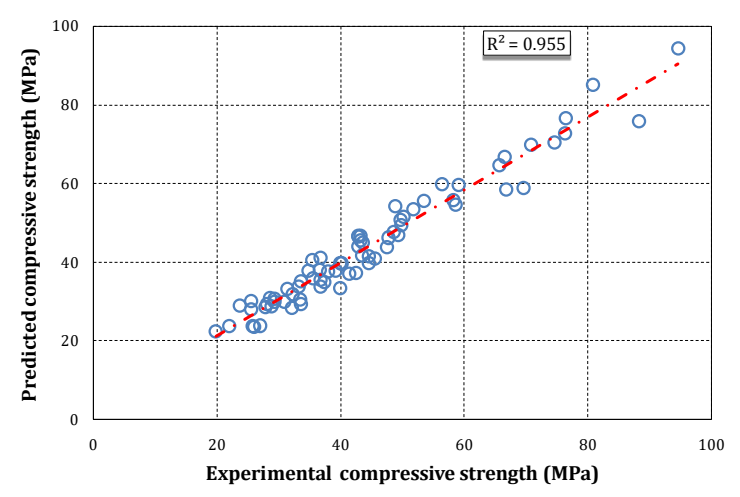

(b)

Figure 5. Predicted versus experimental compressive strength values for a) MLR and b) GEP models and In addition to correlation between the experimental and predicted results, the experimental compressive strength values and predicted values are presented in Figure 6. By this plotting, it was aimed to see that the results achieved by GEP model are closer to the experimental results than obtained by MLR model.

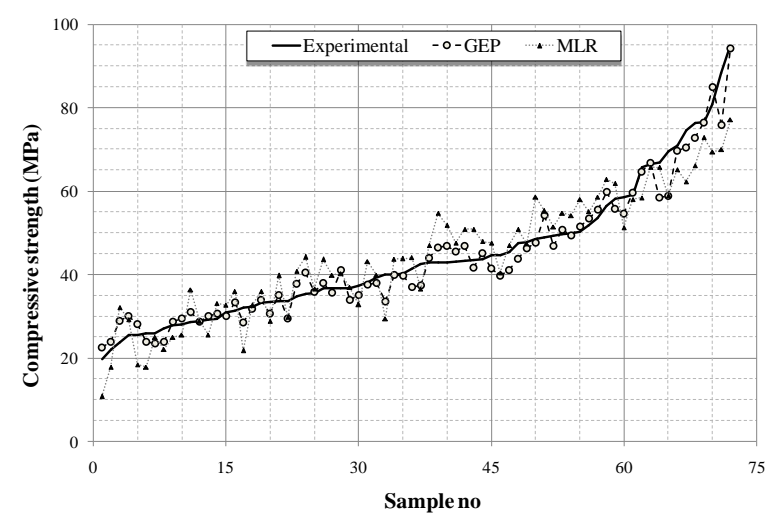

Figure 6. Compressive strengths predicted by MLR and GEP models and experimental compressive strength values versus number of sample

For the purpose of comparison of the predicted and experimental compressive strengths, the strength data obtained from both MLR and GEP model were divided by the corresponding experimental strength values to obtain normalized values. The normalized data versus aggregate-to-cement ratio, cement strength, water-tocement ratio, and testing age are, respectively, shown in Figure $7 \mathrm{a}, 7 \mathrm{~b}, 7 \mathrm{c}$, and $7 \mathrm{~d}$. When the figures are evaluated, it can be obviously found out that almost all GEP model data are scattered in $\pm 20 \%$ limits of the normalized lines whereas some data of MLP model are out of this limit. According to this well distribution of the normalized values, it may be inferred that the prediction formula generated by GEP had an acceptable estimation capability performance. 


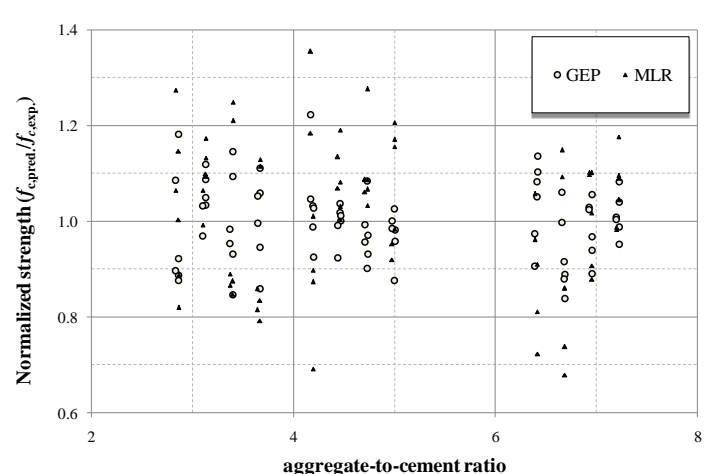

(a)

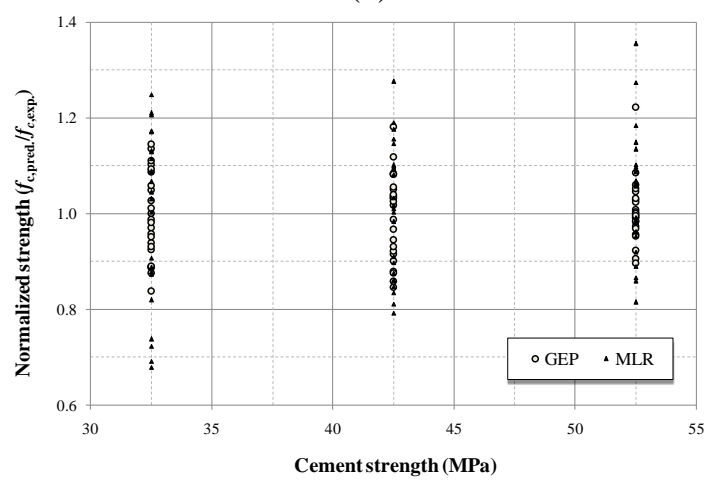

(b)

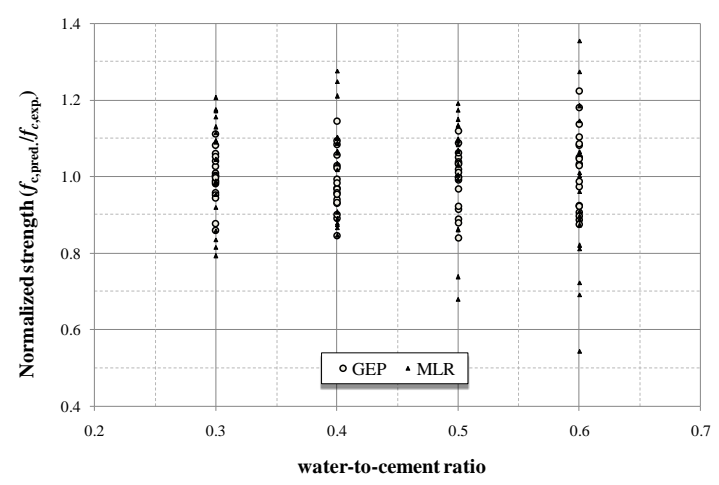

(c)

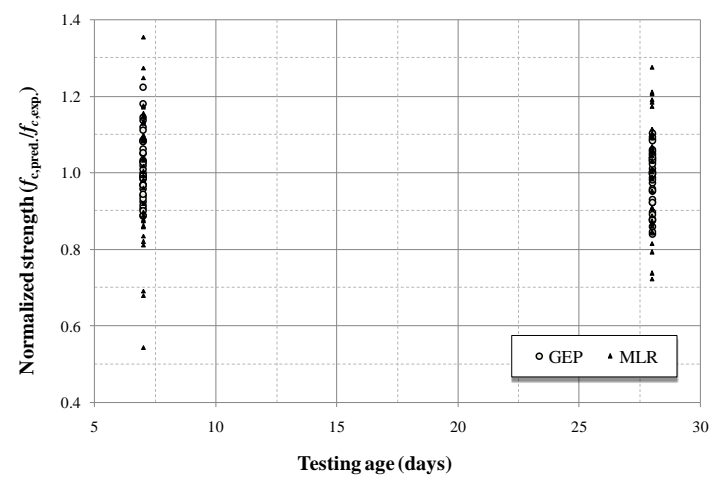

(d)

Figure 7. Prediction performance of the GEP model with respect to: a) aggregate-to-cement ratio, b) cement strength, c) water-to-cement ratio, and d) testing age

\section{Conclusions}

According to the aforementioned discussions, the conclusions below may be reached.

- $\quad$ Reducing the water-to-cement values from 0.6 to 0.3 enhanced the strength performance in all mixture groups.

- Utilization higher strength cement provided higher strength values.

- Cement content has a slight effect on the strength development of the concrete.

- Increasing aggregate-to-cement ratio resulted higher compressive strength of the concrete.

- Statistical analysis revealed that water-to-cement ratio was determined to be the most influential factor on the strength while the cement type and content affected the strength with a lower impact.

- An explicit formula by GEP was proposed using all of the input predictors. It was found out that there is a good correlation between the experimental strength values and those predicted by proposed GEP model. However, the model derived by GEP indicated better estimation performance than MLR model. The high correlation also shows that a reliable analytical model for estimation of strength of concretes produced with different cement types and various mix parameters could be generated by using GEP if there is a plenty of input data.

\section{Conflicts of interest}

The authors state that they did not have any conflict of interests.

\section{References}

[1] BS EN 197-1, Cement: Composition, Specifications and Conformity Criteria for Common Cements British Standards Institution,London, 2000.

[2] Hirschi T., Sika Concrete Handbook Sika Services AG, Zurique, Suíça, 2005.

[3] Mermerdaş K., Gesoğlu M., Güneyisi E., Özturan T., Strength development of concretes incorporated with metakaolin and different types of calcined kaolins. Constr. Build. Mater., 37 (2012) 766-774.

[4] Sayed M. A., Statistical modelling and prediction of compressive strength of concrete.Concrete. Research Letters, 3(2) (2003) 452-458.

[5] Deshpande N., Londhe S., Kulkarni S., Modeling compressive strength of 
recycled aggregate concrete by Artificial Neural Network, Model Tree and Nonlinear Regression, International Journal of Sustainable Built Environment.3(2) (2014) 187-198.

[6] Chandwani V., Agrawal V., Nagar R. Applications of Artificial Neural Networks in Modeling Compressive Strength of Concrete: A State of the Art Review. International Journal of Current Engineering and Technology, 4 (2014) 2949-2956.

[7] Topçu İ.B., Boğa A.R., Hocaoğlu FO., Modeling corrosion currents of reinforced concrete using ANN. Automat. in Constr., 18(2) (2009) 145-52.

[8] Lim C.H., Yoon Y.S., Kim J.H., Genetic algorithm in mix proportioning of high performance concrete. Cem. Concr. Res., 34(3) (2004) 409-20.

[9] Fairbairn E.M.R., Silvoso M.M., Filho R.D.T, Alves J.L.D., Ebecken N.F.F. Optimization of mass concrete construction using genetic algorithms. Comput. Struct., 82(2-3) (2004) 281-99.

[10] Özcan F., Atis C., Karahan O., Uncuoglu E., Tanyildizi H., Comparison of artificial neural network and fuzzy logic models for prediction of long term compressive strength of silica fume concrete, Advances in Engineering Software, 40 (2009) 856-863.

[11] İnan G., Göktepe A.B., Ramyar K., Sezer A. Prediction of sulfate expansion of PC mortar using adaptive neuro-fuzzy methodology. Build Environ 42(3) (2007) 1264-69.

[12] Shahin M.A., Maier H.R. and Jaksa M.B., Predicting settlement of Shallow Foundations using Neural Networks, Journal of Geotechnical and Geoenvironmental Engineering, 128(9) (2002) 785-793.

[13] Topçu İ.B., Sarıdemir M., Prediction of properties of waste AAC aggregate concrete using artificial neural network. Comput. Mater. Sci., 41(1) (2007) 117-25.

[14] Topçu İ.B., Sarıdemir M., Prediction of compressive strength of concrete containing fly ash using artificial neural networks and fuzzy logic. Comput. Mater. Sci.;41(3) (2008) 305-11.

[15] Adhikary B.B., Mutsuyoshi H., Prediction of shear strength of steel fiber RC beams using neural networks. Constr. Build. Mater., 20(9) (2006) 801-11.

[16] Mermerdaş K., Güneyisi E., Gesoğlu M., Özturan T., Experimental evaluation and modeling of drying shrinkage behavior of metakaolin and calcined kaolin blended concretes Constr. Build. Mater., 43 (2013) 337-347.

[17] Duan Z.H., Kou S.C, Poon C.S., Prediction of compressive strength of recycled aggregate concrete using artificial neural networks. Constr. Build. Mater. 40 (2013) 1200-06.

[18] Tokar, A.S. and Johnson, P.A., Rainfall-Runoff Modeling Using Artificial Neural Networks, J. Hydrol. Eng., 4(3) (1999) 232- 239.

[19] Ashour, A.F., Alvarez L.F., Toropov, V.V., Empirical modeling of shear strength RC deep beams by genetic programming. Comput. Struct., 81(5) (2003) 331-38.

[20] Sarıdemir, M., Effect of specimen size and shape on compressive strength of concrete containing fly ash: Application of genetic programming for design, Materials and Design, 56 (2014) 297-304

[21] Lee, S.C. and Han, S.W., Neuralnetwork-based models for generating artificial earthquakes and response spectra. Computers and Structures 80 (2002) 1627-1638.

[22] D'Aniello M., Mete-Güneyisi, E., Landolfo, R., Mermerdaş, K., Predictive Models of the Flexural Overstrength Factor for Steel Thin-Walled Circular Hollow Section Beams, Thin-Walled Structures, 94 (2015)67-78.

[23] Mete-Güneyisi E., Gesoğlu, M., Güneyisi, E., Mermerdaş, K., Assessment of Shear Capacity of Adhesive Anchors for Structures Using Neural Network Based Model, Materials and Structures, (2015) DOI 10.1617/s11527-015-0558-x. 
[24] Mete-Güneyisi, E., D'Aniello M., Landolfo, R., Mermerdaş, K., Prediction of the Flexural Overstrength Factor for Steel Beams Using Artificial Neural Network, Steel and Composite Structures, 17 (2014) 215-236.

[25] D'Aniello M., Mete-Güneyisi, E., Landolfo, R., Mermerdaş, K., Analytical Prediction of Available Rotation Capacity of Cold-Formed Rectangular and Square Hollow Section Beams, Thin-Walled Structures, 77 (2014) 141-152.

[26] Gesoğlu M., Mete-Güneyisi E., Güneyisi E., Yılmaz E., Mermerdaş K., Modeling and analysis of the shear capacity of adhesive anchors post-installed into uncracked concrete. Composites Part B: Engineering, 60 (2014) 716-724.

[27] ASTM C39/C39M-12, Standard test method for compressive strength of cylindrical concrete specimens. Annual book of ASTM Standards, 2012.

[28] Ferreira C., Gene expression programming; a new adaptive algorithm for solving problems. Complex Syst., 12(2) (2001) 87-129.

[29] Li X., Zhou C., Xiao W., Nelson P.C., Prefix gene expression programming. in Late Breaking Paper at the Genetic and Evolutionary Computation Conference (GECCO), Washington, D.C., 2005.

[30] Koza J.R. Genetic programming; on the programming of computers by means of natural selection, MIT Press, USA, 1992.

[31] Gen M, Cheng R. Genetic algorithms and engineering design, Wiley, USA, 1997. 